\title{
Getting By or Getting Ahead: Resettlement Inputs and Social Capital in Involuntary Resettlement
}

\author{
Melissa Quetulio-Navarra ${ }^{1}$, Roger Zetter ${ }^{2}$, Anke Niehof $^{3}$ and Feng Zhao ${ }^{4}$
}

This study goes beyond the conventional evaluative measurement of involuntary resettlement impacts by utilizing the institutions interventions perspective and social capital theory as tools for understanding the extent to which resettled populations in the Philippines and Indonesia are able to restore their socio-economic well-being. The paper outlines how the interplay between the resettlement inputs and social capital changed from the first year in the relocation site to several years later and how the changes provide evidence of the evolving well-being of the households. The cases examined in the study reveal that resettlement inputs and social capital work hand in hand in fostering improvement in the households' living conditions. The research also demonstrates that the value and relevance of household social ties could be context-specific. While the Philippine case presents a 'getting by' picture of households' well-being, the Indonesian case illustrates a combination of 'getting by' and 'getting ahead'.

Keywords: Involuntary resettlement; well-being; social capital; resettlement inputs; Philippines; Indonesia

\section{Introduction}

Since the 1990s, the vulnerability to impoverishment of involuntarily resettled households has been studied using several approaches. These include the Four Stages of Involuntary Resettlement of Scudder (1993) and the Impoverishment, Risks and Reconstruction model of Cernea (1997). The World Bank aims at improving ('get ahead') or at least restoring ('get by') the economic and social base of displaced households (World Bank, 2001). Parasuraman and Cernea (1999) observed that resettlement outcomes are significantly influenced by institutions through their resettlement policies and programs. Institutional perspectives mostly use the models by Scudder and Colson (1982) and Cernea (1997). Scudder and Colson (1982) identified four stages of successful resettlement: recruitment, transition,

\footnotetext{
1 Wageningen University, Wageningen, The Netherlands and Presidential Commission for the Urban Poor, Manila, The Philippines. Email: melisnavarra@gmail.com

2 University of Oxford, Oxford, United Kingdom

${ }^{3}$ Wageningen University, Wageningen, The Netherlands

${ }^{4}$ Chinese Academy of Social Sciences, Beijing, China
}

\begin{abstract}
The research described in this paper is part of the PhD research of Quetulio-Navarra (first author), who was directly involved in the fieldwork in the two study locations. The authors are grateful to the Netherlands Fellowship Programme that funded the fieldwork in the Philippines and the Neys Van Hoogstraten Foundation that funded the fieldwork in Indonesia. Thanks are also due to the households and leaders in the Kasiglahan Village Community and the Bantarpanjang Translok for their participation in the research, Engr. Abeth Matipo of the National Housing Authority, Mr. Candra Musi and Mr. Narso of Perum Perhutani in Indonesia, Dr. Ana Marie Karaos and Ms. Vangie Serrano of Action Group for their assistance in the Philippines, Dr. Sri Sunarti Purwaningsih and Dr. Herry Yogoswara of Indonesian Institute for Sciences (LIPI), Dr. Tyas Wulan of Universitas Jenderal Soedirman, Yayasan Kusuma Buana and the late Dr. Firman Lubis, the Presidential Commission for the Urban Poor, Dennis Sorino and Dulce Joy Sorino, the Philippine Research Assistant Elizabeth Avila, the Indonesian Research Assistant Fanny Dwipoyanthi, and Victor Allan C. Ilagan, Alicia S. Diaz, Martina Robles, and Daniel Vincent.
\end{abstract}


potential development, and handing over or incorporation. The recruitment phase involves the formulation of development and resettlement plans by policy-makers and/or developers, without necessarily informing the affected families. Subsequently, the transition phase takes place where people are informed about the upcoming displacement. After the resettlement of families, potential development occurs and resettled families begin the process of rebuilding their economy and social networks. Years later, the last stage of resettlement takes place in which local production systems and community leadership is handed over to a second generation of residents in the resettlement communities. The resettlement is considered successful once the last stage is reached.

Cernea $(1996 ; 1997 ; 2000)$ highlights the intrinsic risks of impoverishment after displacement, as well as the ways to alleviate these risks through strategic action. The models he developed yield indicators for resettlement inputs that are grouped into hard and soft inputs. Hard inputs include the physical structures constructed within the resettlement site in the form of public places (e.g. streets, sidewalks, markets) and basic services such as electricity, water and daycare centers. Soft inputs pertain to the resettled households' attendance at government meetings and their membership in civic organizations.

Bourdieu and Wacquant (1992, p. 119) defined social capital as the "sum of resources, actual or virtual, that accrue to an individual or a group by virtue of possessing a durable network of more or less institutionalized relationships of mutual acquaintance and recognition." Putnam (2000) refers to social capital as social networks and the norms of reciprocity and trustworthiness that emerge from these. Woolcock and Narayan (2000) stress the importance of both vertical and horizontal ties, associations and relations between people, within and among other entities such as community groups, non-governmental organizations, government agencies, and firms. Poor families use their strong bonding ties of family and kinship to 'get by' or survive, whereas their bridging social capital (horizontal ties beyond family ties) and linking social capital (vertical ties) are crucial in 'getting ahead' or in attaining development and growth (Briggs, 1998). Stone (2001) refers to these ties as structural social capital.

This paper goes beyond the conventional evaluative measurement of resettlement impacts by utilizing the institutional perspectives and social capital theory as tools for understanding the extent to which resettled populations are able to restore their well-being during their first year of residency and several years later. The study illustrates how the interplay between the resettlement inputs and social capital change between the first year in the relocation site and several years later, and how this provides evidence of the evolving wellbeing of the households.

\section{Methodological Design}

Two cases of resettlement communities, one in the Philippines and one in Indonesia, were compared in this study. The cases had in common that the resettlement sites for involuntarily displaced households were built and managed by the government and the resettled households had incomes below the minimum standard of living. The ages of the communities were sufficiently similar. Although comparable in important aspects, the two cases differed regarding cultural traditions, physical location, institutional context, national resettlement policies, religion, ethnicity, and demographic and socio-economic profiles. This allows an analysis of the effect of these differences on the ways in which the resettlers' social 
capital and well-being changed between their first year of residency and the time that fieldwork was conducted several years later.

\section{Setting}

The resettlement site in the Philippines is situated in Barangay San Jose, municipality of Rodriguez, Rizal Province within the Luzon Region. It is a government-managed urban resettlement community named 'Kasiglahan Village 1' (KV1). KV1 has a total land area of 85.7 hectares and 9,915 housing structures. The site was built for poor households evicted because of development projects or natural and man-made disasters. Resettlement of the families who came from different slum communities within Metro Manila started in 1999. The household survey in KV1 was undertaken from April to June 2011.

The resettlement site in Indonesia is located in the village of Bantarpanjang, located in subdistrict Cimanggu of district Cilacap in the province of Central Java. Cilacap is a border area between the parts of Java inhabited predominantly by ethnic Sundanese (i.e. the province of West Java) and those predominantly inhabited by ethnic Javanese (i.e. the provinces of Central and East Java). Cilacap is a mixed Sundanese-Javanese district, with the western part being more Sundanese. The displaced families are Sundanese, as is the population of Bantarpanjang. The institutions of arisan (rotating savings and credit associations) and slametan, which we shall refer to as parties that involve eating together due to life cycle events such as birth, circumcision, marriage, moving house, and death (Guinness, 1986), are found all over Java and beyond.

The cultural emphasis on harmony, which also features in our argument, is particularly prominent among the Javanese, but in an area like Cilacap it is part of Sundanese culture as well. The study site is a government-managed rural resettlement community called 'Bantarpanjang Translok' (BT). BT has a total land area of 3.1 hectares and 97 housing structures. The site was built for poor households displaced by widespread landslides. Although the landslides took place in 2000, it took a year before the housing structures were in place. The community is divided into three blocks called Rukun Tetanga 1 or RT1, Rukun Tetanga 2 or RT2, and Rukun Tetanga 3 or RT3. The site has a total land area of 3.1 hectares and 97 housing structures. It has been accommodating households since 2001. The household survey in BT was conducted from April to June 2012.

\section{Sampling strategy}

The 150 respondents in the Philippines were sampled at random from a sampling frame of 6,144 households who were either 'original house-and-lot owners' or 'rights buyers' who bought the house and lot from the original owner. The Project Office did not have the exact numbers of these two types of residents. Based on qualitative data it was estimated that 30 to 40 percent of the 6,144 households were 'rights buyers'. The 150 respondents were all original owners. In Indonesia, all the 76 beneficiaries of the resettlement project in the Indonesia community were interviewed.

\section{Data collection and measurement}

Several types of data were collected during the fieldwork as described in previous publications (Quetulio-Navarra, Niehof, Van der Horst, Van der Vaart \& Suliyanto, 2012; Quetulio-Navarra, Van der Vaart \& Niehof, 2015; Quetulio-Navarra, Znidarsic \& Niehof, 2017); this paper examines the household profile data only. Similar data collection methods were applied in both sites. A household survey included a household composition sheet and 
a tailored-calendar tool. Qualitative methods included key informant interviews, group interviews, participant and non-participant observations, in-depth interviews and focus group discussions.

The retrospective data collected from the Philippine respondents spanned from 1999 until 2011, while in Indonesia the period examined was from 2001 till 2012. In both cases the households came to the sites in different years, hence the duration of living in the site varies. In this study, only the data in the first and last year in the resettlement site are included, the last year being the year when the survey was conducted (2011 in the Philippines and 2012 in Indonesia).

Household well-being was investigated in economic, physical, and social terms. Economic well-being was measured using data on household income, percentage of household income spent on food, and employment status of the household heads. Physical well-being was measured by utilizing morbidity data. Social well-being of the households was gauged based on reported participation in community activities in the site. Dimensions of structural social capital are investigated by using the numbers of acquaintances, friends, close individuals, government ties, and ties with the church or mosque as indicators.

\section{Analysis of quantitative and qualitative data}

The quantitative data were entered into Excel and analyzed using STATA version 11.The dependent variables under investigation are the three types of well-being, with independent variables measuring the hard and soft resettlement inputs, social capital, and some control variables. Three statistical models were applied in the analysis: a multiple regression model with household income as the dependent variable; an ordered logit model to analyze dependent variables measuring the percentage of income spent on food, employment status of the household head and social well-being; and a Poisson regression model analyzing dependent variables measuring the number of adults who got sick and the number of children who got sick during the periods studied, which frequencies are assumed to follow a Poisson distribution. Content analysis was applied to the qualitative data that were already recorded, translated (in the Indonesian case) and transcribed. The qualitative data are used to validate and complement the quantitative data.

\section{Results}

\section{Philippine Case}

Sixty-eight percent of the respondents were female and 32 percent male. More than half of the respondents were within the age bracket of 25-45. The ages ranged from 20 to 85 . Only 27 percent of the respondents reached college or studied in technical school after high school, 47 percent finished or reached high school, and 25 percent only studied until elementary level. The average household size was 5.58 and the average yearly household income was PHP 88,103.00 (approximately USD 2,066 in 2013).

\section{First Year and 2011 Resettlement Inputs and Social Capital Profile}

Table 1 shows an increase in both the mean number of public places and basic services installed in KV1 since the first year of resettlement. Positive change is visible regarding membership in different civic organizations in the community that gradually increased due 
to encouragement by the National Housing Authority (NHA). The increase in new acquaintances and new friends made during the observed time period can be attributed to frequent visits to public places (store, sidewalks) and community activities (meetings, parties). A mother in the survey said that it was "impossible not to make friends [in KV1] because almost everybody is a stranger to each other and everyday there are newcomers." (In-depth interview, housewife, Kasiglahan, May 2011).

Table 1: First Year and Last Year Resettlement Inputs and Social Capital Profile

\begin{tabular}{|c|c|c|c|c|c|c|}
\hline \multirow[t]{2}{*}{ Profile } & \multicolumn{3}{|c|}{$\begin{array}{l}\text { Philippines } \\
\mathrm{N}=150\end{array}$} & \multicolumn{3}{|c|}{$\begin{array}{l}\text { Indonesia } \\
\mathrm{N}=76\end{array}$} \\
\hline & $1^{\text {st }}$ Year & Last Year & Difference & $1^{\text {st }}$ Year & Last Year & Difference \\
\hline \multicolumn{7}{|l|}{ Resettlement Inputs } \\
\hline \multicolumn{7}{|l|}{ Hard Components } \\
\hline - Mean No. of Public Places & 8.00 & 8.90 & 0.90 & 5.59 & 7.03 & 1.4 \\
\hline - Mean No. of Basic Services & 9.80 & 11.57 & 1.82 & 6.50 & 8.00 & 1.5 \\
\hline \multicolumn{7}{|l|}{ Soft Components } \\
\hline \multirow{2}{*}{\multicolumn{7}{|c|}{$\begin{array}{l}\text { - Attendance Turn-out in } \\
\text { Government Meetings (\%) }\end{array}$}} \\
\hline & & & & & & \\
\hline Never attended & 63.3 & 63.3 & 0.0 & 47.4 & 68.4 & 21.1 \\
\hline Attended & 36.7 & 36.7 & 0.0 & 52.6 & 31.6 & -21.1 \\
\hline \multirow{2}{*}{\multicolumn{7}{|c|}{$\begin{array}{l}\text { - Membership turn-out in } \\
\text { Community Organizations (\%) }\end{array}$}} \\
\hline & & & & & & \\
\hline No membership & 72.0 & 58.7 & -13.3 & 13.2 & 0.0 & -13.2 \\
\hline With membership & 28.0 & 41.3 & 13.3 & 86.8 & 100.0 & 13.2 \\
\hline \multicolumn{7}{|l|}{ Social Capital } \\
\hline - Mean No. of Acq. Made & 5.17 & 5.18 & 0.01 & 5.79 & 2.54 & -3.25 \\
\hline - Mean No. of Friends Made & 4.01 & 4.04 & 0.03 & 4.90 & 1.43 & -3.47 \\
\hline - Mean No. of Close Ind. & 6.52 & 5.67 & -0.85 & 4.24 & 4.84 & 0.60 \\
\hline - Mean No. of Govt. Ties & 0.65 & 0.51 & -0.14 & 0.83 & 0.93 & 0.10 \\
\hline - Mean No. of Church/Mosque Ties & 1.05 & 0.63 & -0.42 & 1.34 & 1.74 & 0.40 \\
\hline - Mean No. of Support Ties & 2.30 & 5.67 & 3.37 & 1.26 & 1.58 & 0.32 \\
\hline
\end{tabular}

The decrease in government and church ties in 2011 implies that the presence of government and church representatives in the site does not automatically translate into the creation of ties. The support ties tell a different story; these had more than doubled by 2011. These are ties the individuals relied on for emotional and financial support, including support in emergencies and for finding employment. Compared to other types of ties, either the number of support ties improved with time or the households' situation in KV1 worsened and, therefore, the households tried to establish more support ties to cushion them from hardships.

\section{First Year and Last Year Well-Being of the Households}

As seen in Table 2, the average annual household income did not improve much after several years in the community (an increase of PHP 21,302 or 26.4\%). If evaluated in the light of the annual poverty threshold for a family of five in the Philippines of PHP 93,852 (USD 2,162 ) and given an average household size of 5.4 in 2011, the average household income of PHP 102,120 (USD 2,358) was barely above the poverty line (National Statistical Coordination Board, 2013). 
Table 2: First Year and Last Year Well-Being Profile of the Respondents

\begin{tabular}{|c|c|c|c|c|c|c|}
\hline \multirow[t]{2}{*}{ Well Being } & \multicolumn{3}{|c|}{$\begin{array}{c}\text { Philippines } \\
\mathrm{N}=150\end{array}$} & \multicolumn{3}{|c|}{$\begin{array}{c}\text { Indonesia } \\
\mathrm{N}=76\end{array}$} \\
\hline & $1^{\text {st }}$ Year & Last Year & Difference & $1^{\text {st }}$ Year & Last Year & Difference \\
\hline \multicolumn{7}{|l|}{ Economic } \\
\hline - Mean Household Income & 80,818 & 102,120 & 21,302 & $4,294,032$ & $4,840,085$ & 546,053 \\
\hline - \% of Household Income Spent on Food (\%) & & & & & & \\
\hline Higher than $80 \%$ & 38.7 & 38.7 & 0.0 & 18.4 & 27.6 & 9.2 \\
\hline From $40 \%$ to $80 \%$ & 47.3 & 48.0 & 0.7 & 59.2 & 51.3 & -7.9 \\
\hline Lower than $40 \%$ & 14.0 & 13.3 & -0.7 & 22.4 & 21.1 & -1.3 \\
\hline \multicolumn{7}{|l|}{ - Household Heads Employment Status (\%) } \\
\hline Neither husband nor wife has a job & 22.7 & 23.3 & 0.67 & 13.2 & 2.6 & -10.5 \\
\hline Either husband or wife has a job & 58.7 & 56.7 & -2.0 & 64.5 & 67.1 & 2.6 \\
\hline Both husband and wife have jobs & 18.7 & 20.0 & 1.3 & 22.4 & 30.7 & 7.9 \\
\hline \multicolumn{7}{|l|}{ Physical } \\
\hline - Mean no. of Ill Adults in the Household & 0.16 & 0.14 & -0.02 & 0.07 & 0.25 & 0.18 \\
\hline - Mean no. of Ill Children in the Household & 0.29 & 0.29 & 0.00 & 0.13 & 0.20 & 0.07 \\
\hline \multicolumn{7}{|l|}{ Social } \\
\hline - Community activities participations (\%) & & & & & & \\
\hline No community activity participation & 53.3 & 53.3 & 0.0 & 13.2 & 11.8 & -1.3 \\
\hline Participated in less than 3 kinds of activities & 36.0 & 32.7 & -3.3 & 14.5 & 44.7 & 30.3 \\
\hline Participated in more than 3 kinds of activities & 10.7 & 14.0 & 3.3 & 72.4 & 43.4 & -29.0 \\
\hline
\end{tabular}

The household head's employment situation also did not improve significantly by 2011 . Some could not retain their jobs in their city of origin because they could not afford the cost of renting a room in the city. Others lost their source of livelihood, as in the case of the families who resettled due to the garbage slide in their previous community in Payatas. The government provided some skills training for the resettlers, like security guard training, reflexology, electronics repair, and candle making. But after the training only few could find a job using these skills and there was no market for products like the candles.

The majority of the household heads would still not join community activities such as meetings, parties, or a wake, even after residing in the community for several years. However, during the fieldwork it could be observed that if the activity involved free goods or services like porridge for the children, rice, or dental care, many mothers, some even carrying their babies, would line up and endure waiting for their turn.

\section{Effects of Resettlement Inputs and Social Capital on Household Well-being}

This section examines the relationship between the resettlement inputs provided by the government in Kasiglahan and the social capital of the households using the information on household well-being in their first and last year in the site. Three regression models were tested in this study with the different measures of well-being as the dependent variables: Resettlement Inputs as Model 1, Social Capital as Model 2, and combined Resettlement Inputs and Social Capital as Model 3 (Table 3). 
Table 3: Effects of Resettlement Inputs \& Social Capital on the Philippine Households' Wellbeing Statistical Analysis, Coefficient, Standard Error

\begin{tabular}{|c|c|c|c|c|c|c|c|c|c|c|c|c|}
\hline \multirow{3}{*}{ Variables } & \multicolumn{4}{|c|}{ Household Income } & \multicolumn{4}{|c|}{ Expenses on Food } & \multicolumn{4}{|c|}{ Employment } \\
\hline & \multicolumn{2}{|c|}{$1^{\text {st }} \mathbf{Y r}$} & \multicolumn{2}{|c|}{ Last Yr } & \multicolumn{2}{|c|}{$1^{\text {st }} Y_{r}$} & \multicolumn{2}{|c|}{ Last Yr } & \multicolumn{2}{|c|}{$1^{\text {st }} \mathrm{Yr}_{\mathrm{r}}$} & \multicolumn{2}{|c|}{ Last Yr } \\
\hline & Coeff. & SE & Coeff. & SE & Coeff. & SE & Coeff. & SE & Coeff. & SE & Coeff. & SE \\
\hline \multicolumn{13}{|l|}{ Model 1 } \\
\hline Gender & $23794.310^{*}$ & 12562.7 & 19302.95 & 15286.26 & 0.401 & 0.360 & 0.396 & 0.353 & -0.232 & 0.372 & -0.302 & 0.360 \\
\hline Age & -523.087 & 517.962 & -741.232 & 631.6217 & -0.016 & 0.015 & -0.021 & 0.015 & -0.013 & 0.014 & $-0.025^{*}$ & 0.014 \\
\hline Household size & 2904.003 & 3028.509 & 3666.591 & 3173.002 & $-0.214^{* *}$ & 0.091 & -0.087 & 0.075 & 0.112 & 0.089 & 0.052 & 0.071 \\
\hline Education level & 3271.332 & 3556.321 & 7019.83 & 4409.577 & $0.187^{*}$ & 0.106 & $0.327^{* * *}$ & 0.111 & -0.005 & 0.102 & 0.067 & 0.101 \\
\hline Location & $-26077.150^{* *}$ & 13138.05 & -22590.01 & 16338.31 & -0.174 & 0.377 & $0.665^{*}$ & 0.390 & 0.175 & 0.379 & 0.128 & 0.374 \\
\hline Basic services & 4730.887 & 3226.253 & 6471.215 & 5128.162 & -0.050 & 0.095 & -0.119 & 0.121 & $0.293^{* * *}$ & 0.099 & 0.083 & 0.118 \\
\hline Civic organizations & -16953.43 & 13226.88 & -10913.62 & 14961.65 & 0.036 & 0.374 & $0.643^{*}$ & 0.356 & -0.201 & 0.392 & 0.149 & 0.348 \\
\hline $\mathrm{R}^{2} /$ Prob>chi2 & \multicolumn{2}{|r|}{$16.1 \%$} & \multicolumn{2}{|c|}{$12.8 \%$} & \multicolumn{2}{|c|}{0.031} & \multicolumn{2}{|c|}{0.003} & \multicolumn{2}{|c|}{0.031} & \multicolumn{2}{|c|}{0.740} \\
\hline \multicolumn{13}{|l|}{ Model 2} \\
\hline Gender & $34822.18^{* * *}$ & 13236.07 & 25870.910 & 15760.710 & 0.519 & 0.377 & 0.467 & 0.376 & -0.115 & 0.383 & -0.345 & 0.379 \\
\hline Household size & 2237.315 & 3074.289 & 2858.700 & 3208.028 & $-0.201^{* *}$ & 0.094 & -0.099 & 0.077 & 0.068 & 0.088 & $0.006^{*}$ & 0.074 \\
\hline Education level & 3596.215 & 3759.344 & $8624.876^{*}$ & 4470.669 & $0.252^{* *}$ & 0.111 & $0.357^{* * *}$ & 0.115 & -0.029 & 0.107 & 0.088 & 0.106 \\
\hline Location & $-26151.19^{*}$ & 13799.12 & -21428.650 & 15839.640 & 0.051 & 0.398 & $0.923^{* *}$ & 0.390 & 0.070 & 0.391 & 0.182 & 0.377 \\
\hline Acquaintances made & -2148.402 & 4899.851 & -3400.187 & 5920.329 & $-0.238^{*}$ & 0.143 & -0.034 & 0.141 & 0.166 & 0.137 & 0.118 & 0.137 \\
\hline Support ties & 177.565 & 2707.543 & 1839.613 & 3174.723 & $0.166^{* *}$ & 0.079 & $0.256^{* * *}$ & 0.077 & 0.122 & 0.078 & $0.232^{* * *}$ & 0.079 \\
\hline $\mathrm{R}^{2} /$ Prob>chi2 & \multicolumn{2}{|c|}{$14.5 \%$} & \multicolumn{2}{|c|}{$15.6 \%$} & \multicolumn{2}{|c|}{0.002} & \multicolumn{2}{|c|}{0.000} & \multicolumn{2}{|c|}{0.570} & \multicolumn{2}{|c|}{0.059} \\
\hline \multicolumn{13}{|l|}{ Model 3} \\
\hline Gender & $29801.14^{\star *}$ & 13251.69 & 26321.360 & 15891.720 & 0.498 & 0.381 & 0.464 & 0.383 & -0.247 & 0.390 & -0.344 & 0.384 \\
\hline Household size & 3856.55 & 3107.533 & 3600.404 & 3234.112 & $-0.199 * *$ & 0.096 & -0.117 & 0.079 & 0.096 & 0.091 & 0.013 & 0.075 \\
\hline Education level & 4345.392 & 3733.425 & $9217.902^{* *}$ & 4526.123 & $0.252^{* *}$ & 0.112 & $0.368^{* * *}$ & 0.119 & 0.008 & 0.108 & 0.112 & 0.108 \\
\hline Location & -22877.28 & 14161.54 & -11013.870 & 16863.930 & -0.007 & 0.419 & $0.998^{\star *}$ & 0.424 & 0.361 & 0.411 & 0.387 & 0.403 \\
\hline Basic services & 5463.882 & 3312.598 & $8901.850^{*}$ & 5182.449 & -0.022 & 0.098 & -0.044 & 0.126 & $0.274^{\star * *}$ & 0.101 & 0.191 & 0.124 \\
\hline Civic organizations & -20514.5 & 13597.98 & -9746.819 & 15350.000 & 0.059 & 0.393 & $0.631^{*}$ & 0.375 & -0.067 & 0.401 & 0.332 & 0.369 \\
\hline Acquaintances made & -5585.165 & 5070.817 & -3902.224 & 6091.907 & $-0.294^{*}$ & 0.152 & -0.032 & 0.147 & 0.154 & 0.145 & 0.138 & 0.143 \\
\hline Close individuals & $3357.518^{*}$ & 1984.055 & 3130.324 & 2480.611 & 0.044 & 0.057 & -0.073 & 0.060 & 0.016 & 0.057 & 0.064 & 0.059 \\
\hline No. of church ties & 5436.038 & 6291.684 & $10087.070^{*}$ & 5866.177 & 0.191 & 0.182 & 0.158 & 0.143 & 0.230 & 0.201 & 0.133 & 0.138 \\
\hline No. of support ties & -721.8424 & 2698.418 & 2742.747 & 3249.314 & $0.168^{* *}$ & 0.081 & $0.292^{* * *}$ & 0.081 & 0.108 & 0.079 & $0.253^{* * *}$ & 0.081 \\
\hline $\mathrm{R}^{2} /$ Prob>chi2 & \multicolumn{2}{|r|}{$19.3 \%$} & \multicolumn{2}{|c|}{$17.9 \%$} & & & & & & & & \\
\hline
\end{tabular}

significant at ${ }^{*} \mathrm{p}<0.10,{ }^{* *} \mathrm{p}<0.05,{ }^{* * *} \mathrm{p}<0.01$ 
continuation of Table 3...

\begin{tabular}{|c|c|c|c|c|c|c|c|c|c|c|c|c|}
\hline \multirow{3}{*}{ Variables } & \multicolumn{4}{|c|}{ Sickness Among Adults } & \multicolumn{4}{|c|}{ Sickness Among Children } & \multicolumn{4}{|c|}{ Community Activity Participation } \\
\hline & \multicolumn{2}{|c|}{$1^{\text {st }} \mathbf{Y r}$} & \multicolumn{2}{|c|}{ Last Yr } & \multicolumn{2}{|c|}{$1^{\text {st }} \mathbf{Y r}$} & \multicolumn{2}{|c|}{ Last Yr } & \multicolumn{2}{|c|}{ Ist Yr } & \multicolumn{2}{|c|}{ Last $\mathrm{Yr}$} \\
\hline & Coeff. & SE & Coeff. & SE & Coeff. & SE & Coeff. & SE & Coeff & SE & Coeff. & SE \\
\hline \multicolumn{13}{|l|}{ Model 1} \\
\hline Gender & -0.207 & 0.467 & $-1.284^{* * *}$ & 0.470 & $-1.075^{* * *}$ & 0.359 & -0.499 & 0.358 & $-0.688^{*}$ & 0.392 & $-0.821^{* *}$ & 0.375 \\
\hline Age & 0.014 & 0.018 & -0.005 & 0.020 & $-0.060 * * *$ & 0.016 & $-0.047 * * *$ & 0.015 & -0.017 & 0.016 & -0.019 & 0.016 \\
\hline Household size & $-0.281^{* *}$ & 0.141 & 0.018 & 0.092 & $0.230^{* * *}$ & 0.086 & $0.171^{* * *}$ & 0.063 & -0.073 & 0.098 & 0.058 & 0.076 \\
\hline Location & $1.259^{* *}$ & 0.623 & -0.023 & 0.583 & $0.755^{*}$ & 0.403 & $0.822^{*}$ & 0.439 & -0.110 & 0.410 & 0.225 & 0.406 \\
\hline Public places & 0.173 & 0.128 & 0.148 & 0.188 & $0.274^{* * *}$ & 0.104 & -0.027 & 0.128 & 0.019 & 0.095 & 0.134 & 0.142 \\
\hline Basic services & $-0.403^{* * *}$ & 0.144 & $-0.328^{* *}$ & 0.140 & $-0.219^{* *}$ & 0.097 & -0.127 & 0.104 & -0.133 & 0.106 & -0.074 & 0.124 \\
\hline Government meetings & $0.816^{*}$ & 0.493 & 0.261 & 0.533 & 0.540 & 0.350 & 0.284 & 0.363 & $2.364^{* * *}$ & 0.403 & $1.541^{* * *}$ & 0.374 \\
\hline Civic organizations & -0.149 & 0.533 & -0.356 & 0.509 & -0.566 & 0.406 & 0.002 & 0.337 & 0.518 & 0.394 & $0.633^{*}$ & 0.352 \\
\hline (Prob>chi2) & \multirow{2}{*}{\multicolumn{3}{|c|}{0.016}} & 0.083 & \multicolumn{2}{|c|}{0.000} & \multicolumn{2}{|r|}{0.000} & \multicolumn{2}{|c|}{0.000} & \multicolumn{2}{|r|}{0.000} \\
\hline \multicolumn{10}{|l|}{ Model 2} & & & \\
\hline Gender & -0.173 & 0.479 & $-1.212^{* *}$ & 0.487 & -0.344 & 0.366 & -0.319 & 0.362 & 0.072 & 0.432 & -0.001 & 0.413 \\
\hline Age & 0.020 & 0.019 & 0.014 & 0.022 & $-0.057^{* * *}$ & 0.019 & $-0.041^{* * *}$ & 0.015 & 0.025 & 0.017 & 0.003 & 0.017 \\
\hline Household size & -0.160 & 0.134 & 0.059 & 0.091 & $0.270^{* * *}$ & 0.098 & $0.170^{* * *}$ & 0.062 & -0.101 & 0.106 & 0.023 & 0.081 \\
\hline Education level & 0.217 & 0.158 & 0.022 & 0.168 & $0.196^{*}$ & 0.119 & 0.103 & 0.113 & -0.029 & 0.130 & 0.067 & 0.123 \\
\hline Location & $1.644^{* *}$ & 0.655 & 0.408 & 0.551 & 1.617 & 0.521 & $1.331^{* * *}$ & 0.440 & 0.412 & 0.455 & 0.434 & 0.416 \\
\hline Acquaintances made & 0.039 & 0.196 & -0.179 & 0.213 & -0.161 & 0.157 & -0.142 & 0.166 & $0.377^{* *}$ & 0.158 & $0.343^{* *}$ & 0.154 \\
\hline Friends made & -0.062 & 0.207 & 0.014 & 0.225 & 0.105 & 0.170 & 0.147 & 0.165 & $0.365^{* *}$ & 0.151 & 0.226 & 0.151 \\
\hline Close individuals & 0.098 & 0.075 & 0.148 & 0.091 & $0.124^{* *}$ & 0.062 & $0.125^{* *}$ & 0.063 & $0.201^{* * *}$ & 0.070 & 0.099 & 0.064 \\
\hline Church ties & 0.157 & 0.221 & $0.274^{*}$ & 0.158 & $0.342^{* *}$ & 0.158 & $0.291 * *$ & 0.119 & 0.255 & 0.194 & 0.234 & 0.147 \\
\hline Support ties & $0.174^{*}$ & 0.096 & $0.184^{* *}$ & 0.093 & $0.349^{* * *}$ & 0.079 & \multirow{2}{*}{\multicolumn{2}{|c|}{0.000}} & -0.045 & 0.096 & \multirow{2}{*}{\multicolumn{2}{|c|}{0.000}} \\
\hline (Prob $>$ chi2) & \multicolumn{3}{|c|}{0.042} & 0.011 & \multicolumn{2}{|c|}{0.000} & & & \multicolumn{2}{|c|}{0.000} & & \\
\hline \multicolumn{13}{|l|}{ Model 3} \\
\hline Gender & -0.091 & 0.507 & $-1.330^{* * *}$ & 0.503 & -0.324 & 0.401 & -0.245 & 0.382 & 0.074 & 0.466 & -0.135 & 0.434 \\
\hline Age & 0.030 & 0.021 & 0.006 & 0.022 & $-0.059^{* * *}$ & 0.021 & $-0.041^{* * *}$ & 0.015 & 0.006 & 0.019 & -0.001 & 0.018 \\
\hline Household size & $-0.241^{*}$ & 0.142 & 0.006 & 0.102 & $0.337^{* * *}$ & 0.112 & $0.143^{* *}$ & 0.070 & -0.152 & 0.116 & 0.039 & 0.085 \\
\hline Location & $1.588^{* *}$ & 0.696 & 0.154 & 0.605 & $1.414^{* *}$ & 0.565 & $1.281^{* * *}$ & 0.473 & 0.554 & 0.502 & 0.711 & 0.471 \\
\hline Public places & 0.223 & 0.140 & -0.011 & 0.198 & 0.099 & 0.114 & -0.145 & 0.156 & $-0.302^{* *}$ & 0.118 & -0.080 & 0.167 \\
\hline Basic services & $-0.367^{* *}$ & 0.143 & -0.225 & 0.151 & -0.087 & 0.100 & -0.051 & 0.112 & -0.110 & 0.127 & -0.049 & 0.139 \\
\hline Government meetings & 0.706 & 0.627 & 0.376 & 0.581 & 0.160 & 0.439 & 0.145 & 0.399 & $1.869^{* * *}$ & 0.473 & $1.153^{* * *}$ & 0.427 \\
\hline Acquaintances made & -0.007 & 0.220 & -0.199 & 0.230 & -0.224 & 0.173 & -0.155 & 0.174 & $0.462^{* *}$ & 0.190 & $0.274^{*}$ & 0.163 \\
\hline Friends made & -0.102 & 0.215 & 0.013 & 0.241 & 0.150 & 0.178 & 0.160 & 0.174 & $0.351^{* *}$ & 0.173 & 0.255 & 0.159 \\
\hline Close individuals & 0.081 & 0.078 & 0.109 & 0.093 & $0.110^{*}$ & 0.063 & $0.122^{*}$ & 0.065 & $0.182^{* *}$ & 0.077 & 0.088 & 0.070 \\
\hline Government ties & -0.061 & 0.255 & 0.030 & 0.230 & $0.278^{*}$ & 0.161 & -0.013 & 0.156 & 0.219 & 0.217 & 0.310 & 0.190 \\
\hline Church ties & 0.170 & 0.226 & $0.271^{*}$ & 0.164 & $0.318^{*}$ & 0.179 & $0.288^{* *}$ & 0.120 & 0.134 & 0.201 & 0.222 & 0.152 \\
\hline Support ties & $0.163^{*}$ & 0.091 & $0.187^{*}$ & 0.105 & $0.328^{* * *}$ & 0.085 & 0.115 & 0.082 & -0.010 & 0.104 & -0.037 & 0.092 \\
\hline (Prob>chi2) & & 19 & & 0.025 & & & & 0.000 & & 0.000 & & 0.000 \\
\hline
\end{tabular}




\section{Economic Well-being}

As generated by the three models, only the variable measuring the number of close individuals influences the increase in household income during the first year of stay in KV1 $\left(\mathrm{R}^{2}=.193\right)$. This provides evidence for the value of establishing and nurturing relationships right after transfer to the site and that investing in social capital pays off. It was observed during the fieldwork that housewives, when not attending to their household chores, regularly gathered to chat with other women in the common space around their houses. Husbands would meet their friends at a 'videoke' party set up on the sidewalk after coming home from their jobs on Saturdays. Although these close individuals might not give financial assistance, the emotional support generated by these relationships probably provides a sense of belonging and peace of mind. One housewife whose husband would only come home from work twice a week said:

\section{During my first year here, my husband could only come home every three days so we could save on transportation fare. But I didn't get lonely because in my first year here I immediately made friends with Rita, Shiela, and Rose. 5 (In-depth interview, housewife, Kasiglahan, May 2011).}

Number of basic services and number of church ties in the past year were entered into the third model $\left(\mathrm{R}^{2}=179\right)$. As seen in Table 1, more basic services were built in later years and more basic services meant electricity and water bills to pay. These financial obligations probably motivated household heads to earn more and avoid the shame of having their water or electric connection disconnected due to default. Furthermore, according to a community leader, during the early years in KV1, people were so preoccupied with solving the problem of insufficient basic services that they would invest much time in asking support from the NGOs and the central and local government. It was only when their demands for basic services were finally granted that they could focus on finding a job or putting up a small business. These outcomes underline the importance of providing resettled households with basic services. Interviews revealed that installing basic services in the site was done piecemeal due to budget constraints. This caused much stress on the households and exacerbated bad conditions at the same time. The site started accommodating households in 1999, but until 2002 households had to contend with insufficient water supplies from a tank and public wells, and only in 2002 could individual households access electricity. The school was built late (in 2001) as well, after plenty of complaints from parents.

People working for the churches in the site (Catholic, Church for Christ, Pentecostal), which were constructed later, were active in recruiting new church members. Church members could be offered voluntary jobs like cleaning the church or assisting at church activities for a minimal fee. Sometimes they would also get hired as household helpers of these church people.

Number of support ties is found to have a positive relationship with expenses on food during the first year $\left(\mathrm{R}^{2} \mathrm{p}<0.01\right)$. As observed during the fieldwork, household heads who reported more acquaintances made in public places and community activities were usually unemployed individuals who had time to frequent public places and attend community activities. They had low incomes and could hardly secure food. On another note, a higher

${ }^{5}$ Names given are pseudonyms. 
number of support ties decreased the odds of food insecurity in the household in the first year in the site. This result affirms the value of support ties (relatives, close friends or a boss) in cushioning some of the shocks of forced resettlement. Such ties benefit the entire household. One woman who was working as a helper in a canteen and who identified her boss as somebody who would help her with food for the family mentioned:

My salary as a helper in the canteen is low, but it is okay. Because whenever I would go home, my boss would let me bring home all the leftovers in the canteen. The leftovers will be our dinner and even my children's lunch in school. This helps me a lot because I can spend my salary in other important matters. (In-depth interview, mother, Kasiglahan, May 2011).

During the past year the number of support ties again was significantly related to economic well-being (Models 2 and $3 p<0.00$ ), proving the consistent value of these strong ties across time. Closer investigation of these support ties showed that most of them remained unchanged from the first year until the year of the field study. Apart from this, membership in civic organizations in KV1 was found to be a significant predictor of household food security. However, the nature of community organizations differs between the first and the last year. During the early years there were only a few organizations (like household associations or HOA, the Action Group), which focused on the urgent provision of basic services. Later on, NHA (National Housing Authority) facilitated the setting up of organizations like women's organizations, church organizations, and transport organizations. These organizations would introduce the community to anti-poverty projects or programs and provide personal assistance to their members.

Regarding getting employed right after resettlement, only the number of basic services were significant predictors in Models 1 and $3\left(\mathrm{R}^{2} \mathrm{p}=0.031\right.$ and 0.059 respectively). As explained above, the payments associated with basic services like electricity and water or the peace of mind when these are available would oblige or motivate a resettler to get a job. In the last year their support ties would increase their likelihood of getting employed as shown in Models 2 and $3\left(\mathrm{R}^{2} \mathrm{p}=0.059\right.$ and 0.097 respectively). Despite the fact that the respondents forged new and different types of ties in their first year, it is still their original support ties that mattered in finding employment several years after resettlement.

\section{Physical Well-being}

Having fewer basic services in the site increases the likelihood of adults getting sick (Model $\left.1, R^{2} p=0.016\right)$. This result underscores the health value of these basic services and the health implications of their absence or insufficiency among the resettlers. Also the number of support ties was found to be significant during the first year (Model 3, $\mathrm{R}^{2} \mathrm{p}=0.019$ ). After several years the number of support ties is still significant as is the number of church ties in both Models 2 and $3\left(\mathrm{R}^{2} \mathrm{p}=0.011\right.$ and 0.025 respectively). This implies that in both periods those households with more adults who get sick might be active in seeking the support of those ties.

Regarding sickness of children during the first year, the relationship with the resettlement inputs indicators measuring the number of public places and the number of basic services is significant (Model 1, $\mathrm{R}^{2} \mathrm{p}<0.00$ ) . While the explanation behind the number of basic services and its relationship with number of sick child(ren) in the family might be the same as for sick adults (see above), the significance of the variable number of public places warrants further examination. Public places in Kasiglahan are, among others, the sidewalks, the deep 
well, the multi-purpose hall, and the basketball court. There are no playgrounds for children. As was observed during the fieldwork, parents would often let their children, even the very young ones play outside unsupervised. The children would be playing with their friends on the sidewalks, the basketball courts, or in the streets, even during the rainy season. When hungry, they would go home and ask for money from their parent(s) to buy (unsanitary) food from the sidewalk vendors or from nearby stores. This may expose them to viruses and to bacteria in the food they buy. The households with children that frequently got sick during the first year of resettlement and the year before the fieldwork relied for help on close individuals, government ties (only in the first year), church ties and support ties (Models 2 and 3, both $\mathrm{R}^{2} \mathrm{p}<0.00$ )

\title{
Social Well-being
}

The extent to which an individual participates in community activities in his/her first year of residency in KV1 can be predicted by two resettlement inputs (participation in government meetings and the number of public places), and three social capital indicators (number of acquaintances, number of friends, and number of close individuals); all Models found these relationships to be significant $\left(\mathrm{R}^{2} \mathrm{p}=0.00\right)$. The positive social effect of participation in government meetings seems to extend to other kinds of meetings, such as community meetings, seasonal community parties and sports events; however, having more public places in the site does not translate into higher rates of participation of household heads in different activities. This finding accentuates the lasting effect of frequent meetings organized by the government. As such, investment should also be directed to undertaking community meetings immediately after resettlement. According to the respondents, the NHA and the local government rarely convened community meetings. This was corroborated by the project manager in-charge of community organizing:

\begin{abstract}
But there is actually no budget for community organizing activities such as community-wide parties or sports activities. We can only afford to conduct a few community meetings with the community leaders and with some residents, and right now because of the expansion of the project and the manpower stays the same we have less time for these activities. (In-depth interview, NHA project manager, Kasiglahan, June 2012).
\end{abstract}

Having more acquaintances, friends, and close individuals increases the odds of participation in community activities.

During the last year, participation in government meetings and membership in civic organizations in KV1 account for the increased participation rate in different community activities (Model 1 with $\mathrm{R}^{2} \mathrm{p}<0.00$ ). Hence, apart from the multiplier effect of government meetings, membership in a civic organization also increases participation in community activities. Unlike the results for the first year, only the number of acquaintances has an impact on the participation of a household head in community activities in Kasiglahan during the last year (both Models 2 and 3 with $\mathrm{R}^{2} \mathrm{p}<0.00$ ).

\section{Indonesia Case}

In Indonesia, 92.1 percent of the respondents were male and 7.1 percent female. Most respondents $(64.6 \%)$ belonged to the age bracket of $41-60$. High school was the highest 
education level reported by the respondents, while 71.1 percent of the respondents had only elementary-level education.

\section{First Year and 2011 Resettlement Inputs and Social Capital Profile}

Table 1 shows an improvement in the number of public places years after the resettlement episode. This also applies to the provision of basic services. Based on an interview with the official in charge of the project, because of lack of budget for basic services the public places were built much later than the houses.

Attending government meetings decreased during the last year. Meetings called by the officials were associated with the urgent needs of the households. When these needs were gradually met, the meetings tapered off. Regarding social capital, the decrease in both new acquaintances and friends made in public places and community activities can be attributed to the decreasing number of households who resettled in Translok in the later years.

Ties with government representatives improved only a little, which is due to the fact that government people would rarely visit the site. The only constant connection with the government they had were with the leaders of their RT and the leader of the BT community (RW). The support ties in the last year were a combination of new and old ones. Among others, these were needed for looking after abandoned farms in the area of origin.

\section{First Year and Last Year Household Well-being}

Table 2 tells us that annual household income only improved a little by 2012 (about $12 \%$ on average). Based on the 2012 annual poverty threshold for a family of four of IDR 11, 698,992 (USD 1,177) (Handayani 2012) and given the average household size of 3.9 in 2012, the annual household income of IDR 4,840,085 (USD 487) is far below the poverty line.

Although household income both during the first and the last year was below poverty standards, only 18.4 percent of the households would spend more than 80 percent of their income on food. The majority (59.2\%) would spend 40-80 percent on food during their first year in Translok. Families would depend more on their personal farms for their daily food needs. Some who lost their gardens to the landslide after transferring to BT were able to arrange a new garden lot where they could plant their crops. Most of the household heads were able to keep their job as farm laborers right after the displacement as BT is closer to the rice fields than their previous place of residence in the mountains. This also allowed the wives to join their husbands in the rice fields as part-time laborers.

Most of the household heads participated in community activities in BT during their first year and in the last year. In the beginning there were introduction parties sponsored by the local politicians, but later on these stopped because the residents all knew each other by then. What remained were parties staged by households at specific occasions (slametan) and gathering for reading the Quran (pengajian). During slametan other households are invited to enjoy a joint meal at the home of the host. In Indonesia, a slametan is organized to highlight life cycle events and at important community occasions. Their purpose is to ascertain the well-being (slamet) of the host family and to promote harmony (rukun) in the community. Participation in and donating to these occasions are a social obligation. Not doing so would make one the subject of community gossip (Guinness, 1986). 


\section{Effects of Resettlement Inputs and Social Capital on the Households' Well-being}

\section{Economic Well-being}

The results in Table 4 show that an increase in the number of basic services has a negative impact on household income during the first year of stay in the site, while membership in civic organizations in BT has the opposite effect (Models 2 and 3, $\mathrm{R}^{2}=.384$ and .425 respectively). The majority of the households came from the nearby mountains where they had access to free drinking water and did not have electricity. After their transfer to BT, basic services such as electricity and water were installed only gradually and had to be paid for. Contrarily, membership in a local civic organization like an arisan (rotating savings and credit associations) seems to have benefited the households economically, as did access to local anti-poverty programs like the rice assistance program Raskin or the cooperative project. Through such programs, some households also had the opportunity to enter into an agreement with the forestry and land-holding agency Perhutani on the utility of some portions of Perhutani land for personal farming needs. Number of acquaintances is positively associated with income, while the number of government ties and the number of support ties both yielded a negative coefficient (Models 2 and 3, R2=0.384 and 0.425 respectively). Two interpretations can be deduced from these results: either those households who had more income during the first year did not need to invest in more ties with the government and individuals who could support them; and/or households with few government and support ties were motivated to work hard and earn more to sustain their living.

In the last year, no resettlement inputs were significant predictors for household income, but the number of government ties (negative coefficient) and the number of mosque ties (positive coefficient) have a significant relationship (Models 2 and 3, R2=.211 and .269 respectively). During the study period it was observed that those who had more government ties are the Rukun Tetanga leaders and active members of organizations. They had direct connections with the village head, some low-ranking officers in Perhutani, and the government agency responsible for the project. The BT residents were aware of this and they would interpret this as a kind of 'power'. Hence, in case of an emergency like death or sickness in the family, people would immediately seek help from these persons who subsequently would give financial assistance (using personal money) and other support.

On the other hand, mosque ties (priest, mosque manager, secretary) can contribute to the improvement of the household income, probably because these ties are a source of information on social services and provide the opportunity to use the mosque's facilities like the public faucet. Persons from two households who were friends with people working for the mosque told us that they regularly got their water from the mosque.

No resettlement inputs or social capital indicators were found to facilitate in making the households more food secure during their first year. In the year of the survey, the decrease in the number of public places and the increase in the numbers of close individuals and government ties are positively associated with household food security (Model 3, with $\mathrm{R}^{2}$ $\mathrm{p}=0.071$ ). The negative association of household food security with the number of public places can be explained by the fact that personal contributions from households (in cash or in kind) were used for building the sidewalks and streets, rather than government funds. Among their different ties, the people seemed to rely on the individuals they frequently engage with when it comes to securing food for their household. Considering that most of the resettlers are farm laborers and that some even maintain their own farm, food exchange 
and food assistance among the neighbors is common practice. While these close individuals can directly provide food to a household in need, government ties (with Perhutani, RT or RW leaders) can provide access to farm lots (lease arrangement) and social projects for the poor (e.g. business capital, livelihood training).

The likelihood of getting employed right after the transfer to BT is positively related with only two social capital indicators: the numbers of close individuals and government ties (Model 2, with $\mathrm{R}^{2} \mathrm{p}<0.00$ ). This highlights the immediate value of forging new close relationships with the other resettlers and government people. Some of the resettlers who were skilled in collecting sap from a gum tree and who knew somebody in the Perhutani office were hired by Perhutani to work in one of their forests. Moreover, the fact that only the number of close individuals emerges as significant implies that access on employment information or job opportunities requires investment in the form of frequent face-to-face interaction. A woman farm laborer told us:

I work as a farm laborer but I don't get to work every day. My work depends on Bu Pasha [pseudonym], a close friend and my neighbor, because she tells me if they need an extra hand in the farm where she works. I get paid IDR 20,000 per day. (In-depth interview, woman-farm laborer, Translok, June 2012).

For the year before the survey, no indicators of resettlement inputs or social capital entered the regression model.

\section{Physical Well-being}

The number of sick adults in the household was only significantly associated with number of basic services during the first year (Model 1, with $\mathrm{R}^{2} \mathrm{p}=0.465$ ). Perhaps this is due to the substandard basic services in the site and the accompanying payments that the household heads had to contend with, which could lead to physical and psychological stress. In the last year, an increase in the number of public places lowers the chances of having sick adults in the family (Model 1, with $\mathrm{R}^{2} \mathrm{p}=0.033$ ). As observed during the fieldwork, the households are generally sociable. People are friendly and would always gather for chats, prayer, parties and meetings in public places. Thus, these public places (e.g. mosque, kiosks, sidewalks) play a central role, not only in the social lives of these households but presumably also in promoting good health.

The number of sick children in the household during the first year in BT is likewise related with fewer public places in the site (Model 1, with $\mathrm{R}^{2} \mathrm{p}=0.079$ ). The site is small (only 1.3 hectares) and only a few public places could be gradually constructed. Even so, the public places seem to be imperative for the children's health. A house in Translok is made of wooden slabs, has no ceiling, no flooring, and no toilet. Staying inside can be rather unbearable because of the heat. One father mentioned that his son would often suffer from fever because of the heat inside their house, but when he started allowing his son to go out and play with his friends on a nearby sidewalk his son stopped getting sick. Later on, he was able to earn more money and put in a ceiling, replaced the wooden walls by brick ones, and cemented the floor. In addition, household heads whose children get sick more often have more acquaintances and few mosque ties (Model 2, with $\mathrm{R}^{2} \mathrm{p}=0.085$ ). For the last year, a positive association was found between the frequency of child sickness and the number of close individuals (Model 3, with $\mathrm{R}^{2} \mathrm{p}=0.101$ ). This could mean that parents whose child(ren) often get sick rely more on their close friends for assistance. 
Table 4: Effects of Resettlement Inputs \& Social Capital on the Indonesian Households' Well-being Statistical Analysis, Coefficient, Standard Error

\begin{tabular}{|c|c|c|c|c|c|c|c|c|c|c|c|c|}
\hline \multirow{3}{*}{ Variables } & \multicolumn{4}{|c|}{ Household Income } & \multicolumn{4}{|c|}{ Expenses on Food } & \multicolumn{4}{|c|}{ Employment } \\
\hline & \multicolumn{2}{|c|}{$1^{\text {st }} \mathbf{Y r}$} & \multicolumn{2}{|c|}{ Last $\mathbf{Y r}$} & \multicolumn{2}{|c|}{$1^{\text {st }} Y_{r}$} & \multicolumn{2}{|c|}{ Last $\mathbf{Y r}$} & \multicolumn{2}{|c|}{$1^{\text {st }} \mathbf{Y r}$} & \multicolumn{2}{|c|}{ Last $\mathrm{Yr}_{\mathrm{r}}$} \\
\hline & Coeff. & SE & Coeff. & SE & Coeff. & SE & Coeff. & SE & Coeff. & SE & Coeff. & SE \\
\hline \multicolumn{13}{|l|}{ Model 1} \\
\hline Gender & -3235843.000 & 3193665.000 & -1077783.000 & 2952200.000 & $1.935^{* *}$ & 0.948 & 0.584 & 0.950 & 0.334 & 1.284 & $3.274^{* *}$ & 1.389 \\
\hline Age & 83161.630 & 78240.420 & 41784.760 & 72273.080 & $-0.063^{* * *}$ & 0.024 & $-0.047^{* *}$ & 0.023 & 0.033 & 0.029 & 0.006 & 0.025 \\
\hline Household size & $1405908.000^{* *}$ & 656871.300 & -6582.104 & 594365.000 & -0.261 & 0.195 & 0.049 & 0.180 & -0.028 & 0.225 & -0.044 & 0.206 \\
\hline Education level & $1711303.000^{* * *}$ & 639246.400 & 32121.600 & 570488.200 & 0.217 & 0.190 & 0.185 & 0.173 & 0.162 & 0.236 & 0.068 & 0.192 \\
\hline Basic services & $-1431560.000^{* *}$ & 708972.400 & 245115.800 & 874159.800 & 0.094 & 0.206 & 0.213 & 0.267 & -0.080 & 0.246 & 0.372 & 0.313 \\
\hline Civic organizations & $12400000.000^{*}$ & 6956749.000 & (omitted) & (omitted) & -0.694 & 2.029 & (omitted) & (omitted) & 38.721 & 7233.398 & (omitted) & (omitted) \\
\hline $\mathrm{R}^{2} /$ Prob $>$ chi2 & $24.8 \%$ & & $7.3 \%$ & & 0.018 & & 0.330 & & 0.000 & & 0.223 & \\
\hline \multicolumn{13}{|l|}{ Model 2} \\
\hline Gender & -1186211.000 & 3050702.000 & -16289.510 & 2867075.000 & $1.987^{* *}$ & 0.995 & 0.603 & 0.948 & -0.188 & 1.092 & $3.535^{* *}$ & 1.426 \\
\hline Age & -850.506 & 75386.710 & -3185.997 & 68187.760 & $-0.044^{*}$ & 0.024 & -0.033 & 0.023 & 0.009 & 0.029 & 0.015 & 0.025 \\
\hline Education level & $1525058.000 * *$ & 573644.100 & -216512.500 & 522601.300 & 0.288 & 0.185 & 0.194 & 0.171 & 0.141 & 0.210 & 0.109 & 0.189 \\
\hline Acquaintances made & $1464149.000^{* *}$ & 634746.700 & 613403.200 & 445403.400 & -0.255 & 0.201 & -0.028 & 0.140 & 0.013 & 0.226 & -0.039 & 0.160 \\
\hline Close individuals & 327174.800 & 313319.200 & 286410.900 & 327400.800 & 0.105 & 0.103 & $0.269^{* *}$ & 0.118 & $0.630^{* * *}$ & 0.142 & 0.141 & 0.125 \\
\hline Government ties & $-2767383.000^{* * *}$ & 951122.300 & $-1391487.000^{*}$ & 769949.100 & 0.231 & 0.322 & $0.503^{*}$ & 0.265 & $0.899^{* *}$ & 0.399 & 0.155 & 0.280 \\
\hline Mosque ties & 911573.200 & 772583.300 & $1452028.000^{* *}$ & 677670.300 & 0.312 & 0.260 & 0.125 & 0.223 & -0.160 & 0.275 & 0.082 & 0.258 \\
\hline Support ties & $-1081530.000^{*}$ & 590280.500 & -308007.800 & 537588.000 & -0.181 & 0.195 & -0.040 & 0.183 & 0.162 & 0.215 & -0.089 & 0.198 \\
\hline R 2 Prob>chi2 & $38.4 \%$ & & $21.1 \%$ & & 0.026 & & 0.127 & & 0.000 & & 0.539 & \\
\hline \multicolumn{13}{|l|}{ Model 3} \\
\hline Gender & -908582.700 & 3058701.000 & 942712.400 & 2892642.000 & $2.093^{* *}$ & 1.033 & 0.855 & 0.999 & 0.032 & 1.811 & $3.482^{* *}$ & 1.425 \\
\hline Age & 1499.299 & 78464.270 & 3479.434 & 71342.210 & $-0.060^{* *}$ & 0.026 & $-0.052^{* *}$ & 0.025 & $0.071^{*}$ & 0.040 & 0.005 & 0.027 \\
\hline Education level & $1624138.000^{* * *}$ & 599371.300 & 120387.000 & 542933.300 & 0.165 & 0.201 & 0.149 & 0.184 & 0.195 & 0.290 & 0.045 & 0.200 \\
\hline Public places & -421060.900 & 942981.700 & 772329.900 & 847648.700 & -0.459 & 0.324 & $-0.682^{* *}$ & 0.290 & 0.261 & 0.409 & -0.205 & 0.331 \\
\hline Civic organizations & $13900000.000^{*}$ & 7833710.000 & (omitted) & (omitted) & -0.339 & 2.538 & (omitted) & (omitted) & 38.401 & 7671.501 & (omitted) & (omitted) \\
\hline Close individuals & 30301.400 & 387419.000 & 257128.900 & 366665.900 & 0.213 & 0.132 & $0.408^{* * *}$ & 0.139 & $0.409^{* *}$ & 0.180 & 0.131 & 0.143 \\
\hline Government ties & $-2928970.000^{* * *}$ & 972120.300 & $-1341062.000^{*}$ & 776276.900 & 0.226 & 0.339 & $0.662^{* *}$ & 0.280 & 0.725 & 0.459 & 0.170 & 0.292 \\
\hline Mosque ties & 959932.300 & 774313.900 & $1641831.000^{* *}$ & 679858.200 & 0.338 & 0.268 & 0.078 & 0.231 & -0.256 & 0.328 & 0.076 & 0.261 \\
\hline Support ties & $-1243254.000^{*}$ & 684414.000 & -416116.800 & 533093.600 & -0.278 & 0.228 & -0.049 & 0.184 & 0.094 & 0.268 & -0.074 & 0.200 \\
\hline $\mathrm{R}^{2} /$ Prob>chi2 & $42.5 \%$ & & $26.9 \%$ & & 0.028 & & 0.071 & & 0.000 & & 0.595 & \\
\hline
\end{tabular}


continuation of Table 4

\begin{tabular}{|c|c|c|c|c|c|c|c|c|c|c|c|c|}
\hline \multirow{3}{*}{ Variables } & \multicolumn{4}{|c|}{ Sickness Among Adults } & \multicolumn{4}{|c|}{ Sickness Among Children } & \multicolumn{4}{|c|}{ Community Activity Participation } \\
\hline & \multicolumn{2}{|c|}{$1^{\text {st }} \mathbf{Y r}$} & \multicolumn{2}{|c|}{ Last Yr } & \multicolumn{2}{|c|}{$1^{\text {st }} \mathbf{Y r}$} & \multicolumn{2}{|c|}{ Last Yr } & \multicolumn{2}{|c|}{$\mathbf{1}^{\text {st }} \mathbf{Y r}$} & \multicolumn{2}{|c|}{ Last Yr } \\
\hline & Coeff. & SE & Coeff. & SE & Coeff. & SE & Coeff. & SE & Coeff & SE & Coeff. & SE \\
\hline \multicolumn{13}{|l|}{ Model 1} \\
\hline Age & -0.038 & 0.054 & $-0.058^{* *}$ & 0.024 & 0.020 & 0.037 & -0.021 & 0.031 & 0.021 & 0.036 & 0.002 & 0.025 \\
\hline Household size & 0.032 & 0.448 & $-0.420^{*}$ & 0.250 & -0.210 & 0.295 & $0.318^{*}$ & 0.190 & $0.683^{*}$ & 0.368 & -0.008 & 0.184 \\
\hline Education level & 0.103 & 0.397 & -0.024 & 0.197 & $0.685^{\star *}$ & 0.282 & -0.186 & 0.247 & 0.087 & 0.371 & -0.007 & 0.184 \\
\hline Location RT 2 & 0.503 & 1.489 & $-1.682 *$ & 0.896 & -0.148 & 1.182 & -1.467 & 0.944 & -0.853 & 1.088 & 0.294 & 0.617 \\
\hline Public places & 0.020 & 0.394 & $-0.301^{*}$ & 0.182 & $-0.833^{* *}$ & 0.420 & -0.210 & 0.587 & 0.379 & 0.403 & -0.017 & 0.223 \\
\hline Basic services & $1.198^{*}$ & 0.685 & 0.449 & 0.281 & 0.222 & 0.291 & -0.110 & 0.226 & 0.392 & 0.352 & $-0.939 * * *$ & 0.307 \\
\hline Government meetings & 1.083 & 1.376 & -0.341 & 0.656 & -0.585 & 1.055 & -0.123 & 0.301 & $2.135^{* *}$ & 1.011 & $1.443^{* *}$ & 0.587 \\
\hline Civic organizations & 5.079 & 3382.545 & (omitted) & (omitted) & 20.666 & 3485.631 & (omitted) & 0.709 & 33.705 & 7050.427 & (omitted) & (omitted) \\
\hline Prob $>$ chi2 & & 0.465 & & 0.033 & & 0.079 & & 0.447 & & 0.000 & & 0.017 \\
\hline \multicolumn{13}{|l|}{ Model 2} \\
\hline Age & -0.066 & 0.052 & $-0.079^{* *}$ & 0.032 & -0.046 & 0.046 & -0.030 & 0.036 & -0.010 & 0.031 & -0.016 & 0.025 \\
\hline Household size & -0.272 & 0.535 & $-0.520^{*}$ & 0.286 & -0.208 & 0.358 & 0.267 & 0.166 & $0.791^{* *}$ & 0.394 & -0.229 & 0.176 \\
\hline Education level & 0.130 & 0.406 & -0.098 & 0.206 & $0.430^{*}$ & 0.257 & -0.279 & 0.264 & 0.429 & 0.397 & 0.097 & 0.170 \\
\hline Location RT 2 & 0.474 & 1.520 & $-1.727^{*}$ & 0.912 & -0.816 & 1.096 & -1.163 & 1.060 & -1.318 & 1.619 & 0.416 & 0.617 \\
\hline Location RT 3 & 1.175 & 1.412 & -0.431 & 0.568 & 0.241 & 0.909 & 0.016 & 0.650 & 0.134 & 1.208 & $1.242^{* *}$ & 0.608 \\
\hline Acquaintances made & 0.471 & 0.349 & $0.304^{*}$ & 0.167 & $0.587^{* *}$ & 0.269 & 0.177 & 0.216 & $1.919^{*}$ & 1.112 & -0.104 & 0.152 \\
\hline Friends made & -0.312 & 0.374 & $-0.409^{*}$ & 0.229 & -0.460 & 0.287 & -0.472 & 0.311 & -1.500 & 1.094 & $0.437^{*}$ & 0.231 \\
\hline Government ties & 0.178 & 0.599 & $-0.635^{*}$ & 0.332 & -0.250 & 0.484 & -0.132 & 0.375 & $3.115^{\star * *}$ & 1.148 & 0.283 & 0.268 \\
\hline Mosque ties & -0.876 & 0.593 & 0.265 & 0.260 & $-0.717^{*}$ & 0.416 & 0.348 & 0.257 & 0.659 & 0.578 & -0.027 & 0.216 \\
\hline Prob>chi2 & & 0.857 & & 0.037 & & 0.085 & & 0.049 & & 0.000 & & 0.401 \\
\hline \multicolumn{13}{|l|}{ Model 3} \\
\hline Gender & 18.699 & 4736.368 & -1.129 & 0.991 & 0.724 & 1.968 & -0.719 & 1.355 & -815.143 & 22900000.000 & -0.155 & 1.038 \\
\hline Age & -0.110 & 0.103 & $-0.091^{* * *}$ & 0.033 & -0.054 & 0.058 & -0.034 & 0.040 & -4.297 & 574658.000 & -0.011 & 0.028 \\
\hline Household size & -0.424 & 0.797 & $-0.687^{* *}$ & 0.310 & -0.644 & 0.641 & $0.358^{*}$ & 0.210 & 78.773 & 7613895.000 & -0.032 & 0.194 \\
\hline Education level & 0.421 & 0.634 & -0.137 & 0.232 & 0.602 & 0.368 & -0.327 & 0.318 & -40.961 & 13400000.000 & 0.012 & 0.191 \\
\hline Location RT 2 & 0.060 & 3.211 & $-1.742 *$ & 1.025 & 0.116 & 1.431 & -0.962 & 1.128 & 106.392 & 25300000.000 & 0.697 & 0.721 \\
\hline Location RT 3 & 1.757 & 2.166 & -0.313 & 0.712 & 1.200 & 1.297 & 0.251 & 0.811 & -127.033 & 43900000.000 & 1.024 & 0.690 \\
\hline Public places & 0.405 & 0.726 & -0.058 & 0.256 & -1.019 & 0.704 & -0.257 & 0.410 & 75.347 & 2016708.000 & -0.441 & 0.308 \\
\hline Basic services & 2.153 & 1.606 & $0.514^{*}$ & 0.309 & -0.065 & 0.327 & -0.251 & 0.428 & 182.730 & 10700000.000 & $-0.818^{* * *}$ & 0.309 \\
\hline Government meetings & 0.426 & 2.845 & -0.073 & 0.811 & -2.052 & 1.780 & -0.323 & 0.957 & 906.628 & 48700000.000 & 0.704 & 0.689 \\
\hline Civic organizations & -5.240 & 9112.384 & (omitted) & (omitted) & 22.611 & 2684.740 & (omitted) & (omitted) & -678.965 & 25900000.000 & (omitted) & (omitted) \\
\hline Acquaintances made & 1.081 & 0.853 & $0.308^{*}$ & 0.179 & 0.377 & 0.338 & 0.203 & 0.217 & 329.407 & 21800000.000 & -0.164 & 0.169 \\
\hline Friends made & -1.218 & 0.966 & -0.371 & 0.277 & -0.021 & 0.399 & -0.380 & 0.350 & -337.696 & 29100000.000 & $0.562^{*}$ & 0.306 \\
\hline Close individuals & 0.103 & 0.383 & -0.074 & 0.141 & -0.037 & 0.217 & $0.256^{*}$ & 0.151 & 13.331 & 9715090.000 & 0.148 & 0.138 \\
\hline Government ties & 0.112 & 1.522 & $-0.806^{*}$ & 0.422 & -0.314 & 0.489 & -0.097 & 0.393 & 237.656 & 20600000.000 & 0.310 & 0.292 \\
\hline Mosque ties & -1.200 & 1.048 & 0.327 & 0.280 & -0.696 & 0.454 & 0.346 & 0.287 & 11.460 & 10200000.000 & -0.141 & 0.238 \\
\hline Support ties & 1.381 & 1.180 & -0.268 & 0.246 & -0.120 & 0.445 & 0.288 & 0.294 & -37.845 & 7057842.000 & -0.011 & 0.191 \\
\hline $\mathrm{R}^{2} /$ Prob $>$ chi 2 & & 0.432 & & 0.047 & & 0.099 & & 0.101 & & 0.000 & & 0.044 \\
\hline
\end{tabular}




\section{Social Well-being}

The participation rate of the Translok households in community activities in their first year of stay in the location can be predicted by their attendance in government meetings (Model 1 , with $\mathrm{R}^{2} \mathrm{p}=0.017$ ) and the number of their government ties (Model 2, with $\mathrm{R}^{2} \mathrm{p}<0.000$ ). This suggests that in order to activate and stimulate the social process among the households in the new community, the government representatives concerned should conduct activities like meetings and parties, so that the residents are introduced to one another and can establish links with the government people themselves.

In the last year, participation to government meetings still positively affects the participation of a household head in community-based activities (Model 1, with $\mathrm{R}^{2} \mathrm{p}=0.017$ ). Apart from this, a higher number of friends is a predictor as well (Model 2, with $\mathrm{R}^{2} \mathrm{p}=0.044$. Surprisingly, having fewer basic services encourages active participation of the households in community activities (Model 1). The community in general shares the same sentiment regarding the persistent problem of the dismal quality and insufficiency of basic services. This issue seemingly creates a bond between the households and gives them a reason to meet and discuss possible solutions, such as raising funds for paving the streets and constructing another mosque in the site.

\section{Conclusions and Discussion}

The cases studied provide strong evidence of the applicability and appropriateness of social capital theory in examining the well-being of households after involuntary resettlement. Likewise, the findings demonstrate the value of breaking down the resettlement program of the government into components and the social capital into different types of ties when investigating their impacts on household well-being. The study makes the role of the resettlement program and people's social capital in getting by and getting ahead visible and shows how the outcomes differ according to resettlement policies, culture, location, and context of resettlement (first year and last year).

The cases reveal that resettlement inputs can both facilitate and hamper households to get by and get ahead. Building more public places in the Philippines brings a negative effect on the health of the children as the parents allow them to roam around and play without adult supervision. In Indonesia, the public places provide an escape for the children from the sweltering heat inside the wooden houses and for the adults serve as venues for nurturing relationships through different activities. These contradicting results can be attributed to the different location and size of the resettlement sites. Kasiglahan is located in an urban area and is much larger than BT (the population is 81 times that of BT), so that children's movements are hard to monitor. Thus, resettlement project managers together with the community should be more alert to the utilization of the public places in the site and pay attention to how these can contribute to the well-being of the residents.

Similarly, paying for basic services seems to be acceptable to the urban resettlers in KV1 also during their first year while they were still struggling to get by, whereas the rural resettlers in BT view payment as an additional burden and, therefore, a barrier in getting by. The majority of the KV1 households came from urban areas where they were used to using and paying for electricity and water, would walk on paved streets, and had access to daycare and health centers. Hence, they expected the same kind of facilities in Kasiglahan. They 
were also aware that these basic services should be provided to them according to official resettlement policy. Contrastingly, the BT resettlers came from the nearby mountains and were not used to electricity and pipe-borne water. The communal toilets installed in the site were also a novelty; in the mountains the river and streams were used for sanitation, which did not require them to line up and wait for their turn. They were psychologically and financially not prepared for the new situation. Probably much stress could have been avoided if orientation meetings with the households had been conducted prior to the resettlement to inform them about the upcoming changes in their living conditions. That could have resulted in practical solutions to mitigate the social costs of resettlement.

Overall, the soft resettlement inputs are found indispensable for the households' capacity to get by and get ahead in both locations. Government meetings and membership in local civic organizations contribute positively to food security (last year) and social well-being (both years) of the Philippine resettlers, and to household income (first year) and social well-being in both periods for the Indonesians. This highlights the overarching value of the government's engagement with the resettlers and facilitating civic organizations in the site. Therefore, resources and activities for community organization should be integral parts of resettlement projects.

All the forms of structural social capital turned out to be useful for getting by and getting ahead, though some types of ties seemed more valuable than others. In KV1, the number of support ties played a prominent role in the economic and physical well-being of the households, whereas in BT it is the number of close individuals and number of government ties (for few people) that mattered most. Interestingly, for the Philippine households, despite the number of new friends, close individuals, and ties with other entities during the first and the last year, the role of support ties remained crucial for their well-being. This conveys that the KV1 households in spite of the turmoil brought about by the involuntary resettlement process still managed to maintain their ties with people whom they can rely on for support. They are aware of the worth of these ties and even added more individuals to their support network over time. This would support the claim of Putnam, Leonardi and Nanetti (1993) that for the poor, social capital is a substitute for other capital that they lack. However, there is a downside to this as well. Most of the KV1 households even after so many years in the resettlement site remain in the 'getting by' state. They would mostly rely on their existing support ties and fail to branch out their support network. It was apparent during the field work that residents in the site generally assume that all of them are poor and that therefore they cannot help each other with money, food, or employment. This was corroborated by a focus group discussion with household heads in which the participants shared that despite having new close individuals in their lives, they would not ask them for help because these people were equally poor and in need of assistance. Unfortunately, few government meetings and the absence of distinctive social activities reinforce this reliance on existing support ties.

The support network of the BT resettlers is more diverse, as it comprises close individuals and government ties. This diversity, which is sustained by their continued farming activities, cultural institutions of slametan and pengajian (see above), possibly aided the households in getting ahead in terms of food security, employment, and social well-being. In a similar study by Quetulio-Navarra, Niehof, Van der Vaart, Horst and Suliyanto (2012) the Indonesian culture of partying and meetings was found to be crucial for building reciprocity among the newly-resettled neighbors. Moreover, this finding related to their few government ties provides evidence on the similar claims of Briggs (1998) and Woolcock and Narayan (2000) that linking ties or vertical ties (in this case, the RTs and RW and the 
government people of Perhutani) of the poor can lead them to development and growth. Clearly, the Translok case demonstrates how culture can be a resource in building a new community and that can compensate for the absence of government program on community organizing. The strong cultural mechanisms for socializing found in Translok enhanced social cohesion and solidarity among new community members. In contrast, the KV1 community lacks this kind of cultural institution and therefore relies heavily on government intervention in building their community. Notwithstanding, the predominance of horizontal ties in the families' (in both cases) social capital questions Woolcock and Narayan's (2000) assertion, as well as that of other social capital experts, that vertical ties are more valuable than horizontal ties to poor families or individuals for getting ahead in life. What the study shows is that poor families, although exposed to vertical ties (government personnel), still heavily rely on their horizontal ties (friends, family) for both getting by and getting ahead. The argument on vertical versus horizontal ties for poor people needs further research that generate evidence on how vertical ties actually work for poor families involuntarily resettled.

The two sites also illustrate that when designing community organizing programs, resettlement proponents or project managers should know the sociability pattern or culture of the resettlers in order for them to be effective. Equally important is the sustainability of the government engagement with the community leaders and with the residents as well, which as illustrated in the study can result into the creation of linking ties which the poor households can explore for getting by and getting ahead.

The research also points out that the value of different social ties for the households is context-specific. As illustrated by the case of improving household income in Kasiglahan, during the first year period close individuals are found important but in the last year it is the church ties that would positively influence their income. In the case of BT, acquaintances were found useful for improving household income during the first year, but in the last year it is their mosque ties that count for the BT households. This shows that for a resettlement program it is imperative to recognize the potent role of the religious institutions in the restoration or improvement of the resettlers' income by integrating the households into programs and crafting novel activities or projects.

The Philippine case presents to us a static or 'getting by' picture of the households' wellbeing. The Indonesian case mirrors a combination of 'getting by' in terms of household income and food security and 'getting ahead' for other indicators of well-being. Finally, it can be concluded that resettlement inputs and social capital work in tandem to foster the improvement of the households' living conditions.

\section{References}

Bourdieu, P. \& Wacquant, L. (1992). An invitation to reflexive sociology. Chicago: University of Chicago Press.

Briggs, X. D. S. (1998). Brown kids in white suburbs: Housing mobility and the many faces of social capital. Housing Policy Debate, 9(1): 177 - 221.

Cernea, M. (1996). Impoverishment risks and livelihood reconstruction: A model for resettling displaced populations. Washington, D. C.: World Bank.

Cernea, M. (1997). The risks and reconstruction model for resettling displaced populations. World Development, 25(10): 1569-1588. doi: 10.1016/S0305-750X(97)00054-5

Cernea, M. (2000). Risks, safeguards and reconstruction: A model for population displacement and resettlement. Economic and Political Weekly, 35(No. 41): 3659-3678. 
Guinness, P. (1986). Harmony and hierarchy in a Javanese Kampung. Singapore: Oxford University Press. Handayani, I. (2012, February 15). Beyond statistics of poverty. The Jakarta Post. Retrieved from http://www.thejakartapost.com/news/2012/02/13/beyond-statistics-poverty.html

National Statistical Coordination Board. (2013). Poverty incidence unchanged, as of first semester 2012. Makati: National Statistical Coordination Board.

Parasuraman, S. \& Cernea, M. M. (1999). The development dilemma: displacement in India. Basingstoke: Macmillan.

Putnam, R. D. (2000). Bowling alone: The collapse and revival of American community. New York: Simon \& Schuster.

Putnam, R. D., Leonardi, R., \& Nanetti, R. Y. (1993). Making democracy work: civic traditions in modern Italy. New Jersey: Princeton University Press.

Quetulio-Navarra, M., Niehof, A, Van der Vaart, W, Horst, H. \& Suliyanto, S.E. (2012). The disruption and rebuilding of social capital in involuntary resettlement in the Philippines and Indonesia. International Journal of Social Sciences and Humanities Studies, 4(2): 307-323.

Quetulio-Navarra, M., Van der Vaart, W. and Niehof, A, (2015). Can third-party help improve data quality in research interviews? A natural experiment in a hard-to-study population. Field Methods Journal. 27(4): 426-440. doi: 10.1177/1525822×15572096

Quetulio-Navarra, M., Znidarsic, A. and Niehof, A. (2017). Gender perspective on the social networks of household heads and community leaders after involuntary resettlement. Gender, Place $\mathcal{E}$ Culture, 24(2): 225-246. doi: 10.1080/0966369x.2016.1277185

Scudder, T. (1993). Development-induced relocation and refugee studies: 37 years of change and continuity among Zambia's Ovenbe Tonga. Journal of Refugee Studies, 6(2): 123-152. doi: $\underline{10.1093 / j \mathrm{js} / 6.2 .123}$

Scudder, T. \& Colson, E. (1982). From welfare to development: A conceptual framework for the analysis of dislocated people. In A. Hansen and A. Oliver-Smith (Eds.), Involuntary migration and resettlement: The problems and responses of dislocated people (pp. 267-287). Boulder, USA: Westview Press.

Stone, W. (2001). Measuring social capital: Towards a theoretically informed measurement framework for researching social capital in family and community life. Melbourne: Australian Institute of Family Studies.

World Bank (2001). OP 4.12 - Involuntary Resettlement. Washington: World Bank.

Woolcock, M. \& Narayan, D. (2000). Social capital: Implications for development theory, research, and policy. World Bank Research Observer 15(2): 225-249. doi: 10.1093/wbro/15.2.225 